Mark $D$. Flood is an economist at the Federal Reserve Bank of St. Louis. David H. Kelly and James P. Kelley provided research assistance.

\title{
Two Faces of Financial
}

\section{Innovation}

I ON HAS ALWAYS been a hallmark inancial services industry. Indeed, the history of finance can be organized as a chronicle of innovations. We can trace this history from the introduction of coinage in the Greek state of Lydia in the 7th century B.C., through the various ploys to circumvent the Christian and Islamic bans on usury in the medieval era, through the development of modern systems of insurance in the 18th and 19th centuries, on up to more timely innovations such as foreign currency exchange warrants and interest-rate swaps. ${ }^{1}$

Recent innovations have ranged from the commonplace - the automatic teller machine (ATM), for example - to the arcane - exchangetraded options to buy futures contracts on municipal bond index funds. Indeed, the range

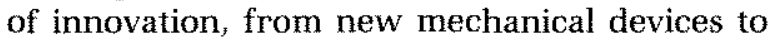
new contractual arrangements to new operational procedures, is so broad as to confound concise definition of the term. ${ }^{2}$ Moreover, inno- vations have recently arrived at a frenetic pace; in the narrow field of exchange-traded futures, for example, Silber (1981) lists 102 new contracts introduced in the United States in the 1970s alone.

In response to the pace and diversity of financial innovation, economists have studied the economics of innovation. Two largely distinct - but not necessarily inconsistent - approaches to the subject have developed over the last 20 years. One approach, motivated by the imperfect success rate for new securities, has focused on improving financial products by applying the principles of finance theory to the process of contract design in securities markets. ${ }^{3}$ The second approach, motivated largely by central bankers' concerns about the effect of innovations on monetary policy, has focused on the reasons why financial innovation occurs. This approach has examined the incentives for people to develop new financial contracts or technologies. ${ }^{4}$ Using two case studies, this paper illus-

\footnotetext{
1 See Goldsmith (1987) for some descriptions of financial institutions and instruments throughout history.

2Schumpeter (1939) defines an innovation as a change in the shape of the production function. He goes on to categorize innovations as being either "process" or "product." Process refers to innovations that permit an ex" isting product or service to be provided more cheaply. Product refers to innovations that introduce a product or service that was previously unavailable. The ATM, for example, is a mixture of both types. An ATM provides many routine services, such as accepting deposits and disburs-
}

ing withdrawals, and usually does so more cheaply. At the same time, an ATM can provide services that were previously unavallable, such as nighttime and weekend withdrawals.

3Some examples are Allen and Gale (1988), Chen and Kensinger (1990), Johnston and McConnell (1989), and Silber (1981).

${ }^{4}$ Some examples are Goodhart (1986), Kane (1984), Podolski (1986), Rasche (1988), and Simpson (1984). 
trates how financial innovations arise to meet a perceived demand for new financial services. The contrasting experience of the two cases shows how market forces can spell failure for product designs that do not attend to the principles of financial theory and success for those that do.

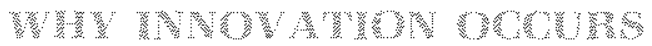

In general, individuals do not innovate out of a spirit of magnanimity. Indeed, we shall assume, as we do with other economic behavior, that financial innovations are created in anticipation of material gain. Most theories of the incentives to innovate can be understood in terms of a cost-benefit analysis: new potential profits are the incentives to innovate. These arise when a change occurs that makes possible either a reduction in costs, an increase in revenues, or both. For simplicity, such changes are usually treated as occurring exogenously to the financial services industry, even when this depiction is not entirely accurate.

On the cost-reduction side of the cost-benefit interpretation, exogenous technological change is the force most often cited as producing the potential cost reductions that can induce innovation. As we shall see below, the transaction costs and the costs of market illiquidity are two factors that frequently affect the production and success of financial innovations. Advances in computing power, for example, have lowered the cost of such accounting-intensive products as brokered deposits and mutual funds. Other products relying on rapid calculation and decision, such as portfolio insurance and index arbitrage transactions, have similarly been made feasible by increases in computer speed. The ATM, which reduces bank operating costs by efficiently executing much of a teller's drudgery, was made possible by gains in both computing power and miniaturization.

Some of these innovations can also illustrate the other side of the incentive to innovate - the potential for increased revenues. Activities like index arbitrage would be inconceivable without some form of reliable, high-speed calculation; computers can thus be seen either as reducing the potential cost of the activity from infinity or as increasing potential revenues above zero.

More commonly cited as forces that can generate potential sources of new revenue are government policy and inflation. ${ }^{5}$ The tax code, in particular, offers numerous incentives. Taxpayers innovate to exploit loopholes and avoid assessments (for example, tax-free municipal bond mutual funds). If taxpayers are successful in using financial innovations to lower their tax bills, government may seek to re-legislate to close loopholes and expand the scope of taxation. Completing the cycle - in what Kane (1977) has called the "regulatory dialectic" taxpayers find new incentives in the revised tax code and innovate again. Broad-based macroeconomic factors can also motivate innovation. For example, inflation combined with deposit interest rate ceilings in the late 1970s and early 1980 s to produce new kinds of bank deposits super-NOW accounts and money-market mutual funds - which function essentially as interestbearing checking accounts. More recently, the Coffee, Sugar and Cocoa Exchange experimented unsuccessfully with consumer price index (CPI) futures, which were to have allowed investors to hedge against inflation.

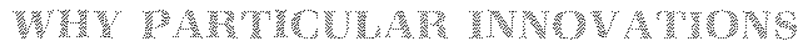 8}

Creators of financial innovations are obviously interested in whether their innovations will succeed in the marketplace. Success, of course, is not automatic. For example, as Marton reports, "some exchange officials privately admit that they put out new futures products pretty much the way a cook tests his spaghetti strands - by flinging them against the wall to see if any of them stick." ${ }^{\prime 6}$ Because innovation is not costless, however, it is important that innovators have a more systematic approach to innovation than primitive trial and error.

To examine the successfulness of specific innovations, we must first have some way of measuring success. Because we have assumed that people innovate in hopes of profit, a measure of success should either measure the inno-

\footnotetext{
sSee, for example, Kane (1984) or Miller (1986).

6See Marton (1984), p. 239. Alchian (1977), pp. 30-32, discusses the role of trial and error in the process of innovation, and he equates success with survival. He notes ( $p$. 31) that "the available evidence [that the necessary condi-
}

tions are met under which trial and error converges to a profit-maximizing equilibriuml seems overwhelmingly unfavorable." For our purposes, defining success as survival is not precise enough to be useful, since even failures will survive at least briefly before their demise. 
vator's profits directly or, at least, be correlated with those profits. In many cases, a measure of popularity can proxy for success. For example, an exchange that introduces a new security might measure success by dollar trading volume in the new contract. Given a measure for success, innovators can set about designing a product to maximize that measure.

Some of the factors leading to a successful innovation are illustrated in the following example. The economist Milton Friedman, anticipating a devaluation of the British pound in the early 1970 s, discovered he could not speculate on his beliefs, because no bank would allow him to sell the pound short. Hearing of his plight (and presuming that his predicament was not unique), Leo Melamed and the Chicago Mercantile Exchange (CME) launched the International Monetary Market (IMM). The IMM trades, among other things, foreign currency futures, which allow investors to speculate on devaluations for appreciations) of the pound. This innovation has been successful because the CME found a trade that investors wanted to make, but could not, and it devised an instrument that allows them to do so cheaply and reliably (an exchangetraded foreign currency futures contract)."

A more general application of this recipe for success must answer several questions. For example, how is an innovator to know which as yet non-existent security investors want to trade? A full answer to this requires considerable insight into investor demand. Famous economists may offer suggestions, but this process is not always reliable. Milton Friedman, for example, also advocated the failed CPI futures contract. ${ }^{8}$

A secondary problem is knowing whether investors can already make a certain type of trade. While the answer might seem readily obtainable, the existence of substitutes is not always obvious. In the futures markets, for example, hedging a commodity position with a futures contract on a close substitute (cross-hedging) may be adequate or even superior to hedging directly. ${ }^{9}$ Identifying these possibilities and how they might be used can be quite subtle. Such subtleties can play a role in determining the success or failure of a new financial product. These issues play a prominent role in our first case study.

Nonetheless, some rules of thumb do exist for identifying likely successes in futures markets: contracts based on commodities that are easily standardized, have large price volatility, and have enough suppliers and demanders to create a liquid market. ${ }^{10}$ These rules are far from foolproof, however. Moreover, they do not generalize automatically to other types of innovations. Indeed, codification of the elements of successful innovation as a collection of rules is almost certainly impossible; it is also beyond the scope of this paper. Instead, we illustrate with two case studies the more general ideas of the incentives to innovate and the application of financial principles to real innovations.

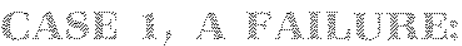 GA}

The first innovation we consider is a futures contract on bagged Canadian silver coins, introduced by the IMM. This innovation was a failure. After 13 months of meager trading, the IMM discontinued the unpopular and unprofitable contract. Why did this contract fail? There is an answer that is consistent with both our theoretical rationales for successful financial innovation and with the facts: A good cross-hedge existed in the much more liquid silver futures market. There, hedgers could achieve similar results at lower cost.

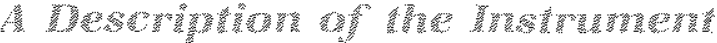

On October 1, 1973, the IMM opened trading in a new futures contract on Canadian silver coins. The purchaser of a contract promised to pay a certain future amount in U. S. dollars (USD) at a specific future maturity date; in exchange, the purchaser would receive future delivery of five bags of Canadian silver coins (dimes, quarters or half-dollars), with each bag worth 1,000 Canadian dollars (CAD) at face value. Different denominations could not be
7See Miller (1986), p. 464. Similar speculation was possible in the interbank market for forward foreign exchange. Individual investors, like Friedman, are generally excluded from this maket, however.

Innovations like this, that expand the possibilities for ex change, are generally Pareto-improving. That is, they can make everyone involved better off. See, for example, Flood (1991).

BSee Friedman (1984)
"A useful concept in this regard is "redundancy." If the price of a good is always a fixed multiple of the price of another good, so that the price changes for the two are always perfectly correlated, then one of the goods is said to be redundant

toSee Black (1986), pp. 5/12. 
mixed within a bag, and the coins were to have been minted before 1967, with the exception that a bag could contain up to 2 percent 1967 or 1968 coins containing at least 50 percent silver. ${ }^{11}$

The contract was presumably intended to afford commercial banks holding vault inventories of silver coinage the opportumity to hedge their positions. In the mid-1960s, both the United States and Canada had phased out the use of silver in their coinage. In an application of Gresham's Law - "Bad money drives out good" - both banks and private investors hoarded silver coins for the bullion content, using instead the new, non-silver coinage as a transactions medium. ${ }^{12}$

The hoarded Canadian silver coins might be valuable for two reasons. First, they were Canadian currency and, therefore, could be exchanged for goods and services in Canada. Second, they contained substantial amounts of silver, a mineral with numerous industrial uses. ${ }^{13}$ Therefore, their USD value could fluctuate with changes in the USD/CAD exchange rate or with changes in the USD price of silver. Banks wishing to protect themselves against such price fluctuations could simply sell their stores of the coins, or they could sell the new futures contracts, which would lock in a future sale price for their inventory. As we shall see, however, indirect hedges were also available.

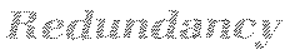

We are interested in factors contributing to the failure of the IMM's futures contract on the coins. One way to explain this failure would be to find some other security that provides the same risk allocation more cheaply. In other words, we can explain failure by establishing the existence of an efficient cross-hedge for the futures contract. It turns out that, subject to some caveats, we can demonstrate that the coinage contract was indeed redundant.

In doing this, it would be helpful to understand theoretically why the price of the crosshedging instrument should be correlated with the price of the coinage futures contract. With this in mind, we examine the dual role as either silver or currency) of the coins more closely.

At any time, the coins could be used for one of two purposes: as a stock of raw silver for industrial purposes, or as a medium of exchange for transaction purposes. The coins clearly could not be used for both purposes simultaneously: industrial use would require melting the coins; monetary use would require not melting them. Instead, if the coins were removed from bank vaults and put to use, we should expect them to go to the more valuable of the two uses.

These relationships are presented in figure 1. This surface is a plot of the value of coins as a function of the USD/CAD exchange rate and the USD value of silver. Given coordinates for the USD value of silver and the USD value of Canadian dollars, the height of the surface at that point is the value of the bagged Canadian coins. The graph formalizes the notion that the silver coins are worth the larger of two values: their value as silver or Canadian currency. The axes are scaled to correspond to contract specifications in the futures markets. The units on the CAD axis give the USD value of CAD 100,000, the contract size for a foreign exchange futures contract. Similarly, the silver axis gives the USD value of 5,000 troy oz, of silver, the contract size for a silver futures contract at the Chicago

\footnotetext{
${ }^{11}$ See IMM (1973a), p. 22. Because the payoffs described here are all in U. S. dollars, it may be helpful to imagine that the hedging institution is a U. S. bank. Regardless, the nationality of the parties involved should not affect in any way the pricing relationships discussed below.

12The new coins consisted of a copper core clad in a copper-nickel alloy: they contained no silver. The Board of Governors of the Federal Reserve (1970) ruled that vault inventories of U. S. silver coins held by commercial banks for their own account could still be counted as part of required reserves, even though they were being hoarded and therefore would not circulate. Coins to which the bank did not have "the full and unfestricted right" - for example, coins held for safekeeping in the name of a speculating depositor - would not satisfy reserve requirements.

13MM (1973a), p. 20, suggested that the numismatic value of the coins might also be a factor. The possibility that bagged coins might have significant numismatic value is
}

remote, however. Collectors grade coins according to quality (e. g., proof, uncirculated, very fine, etc.). With rare exceptions, coins of recent minting are priced above face value, only if they are rated as proof or uncirculated. The fact that the coins subject to the futures contract were poured loose into bags implies that they could not be rated proof of uncirculated. Indeed, the "sweating" of coins, i. e., shaking them loose in a bag to rub off silver shavings, is a traditional means of debasing a currency. The ABA (1965), p. 8 , for example, claimed that it was "obvious that it will be years and years before these coins have any value as collectors items." 


\section{Figure 1}

\section{Theoretical Relationship Between Spot Prices}

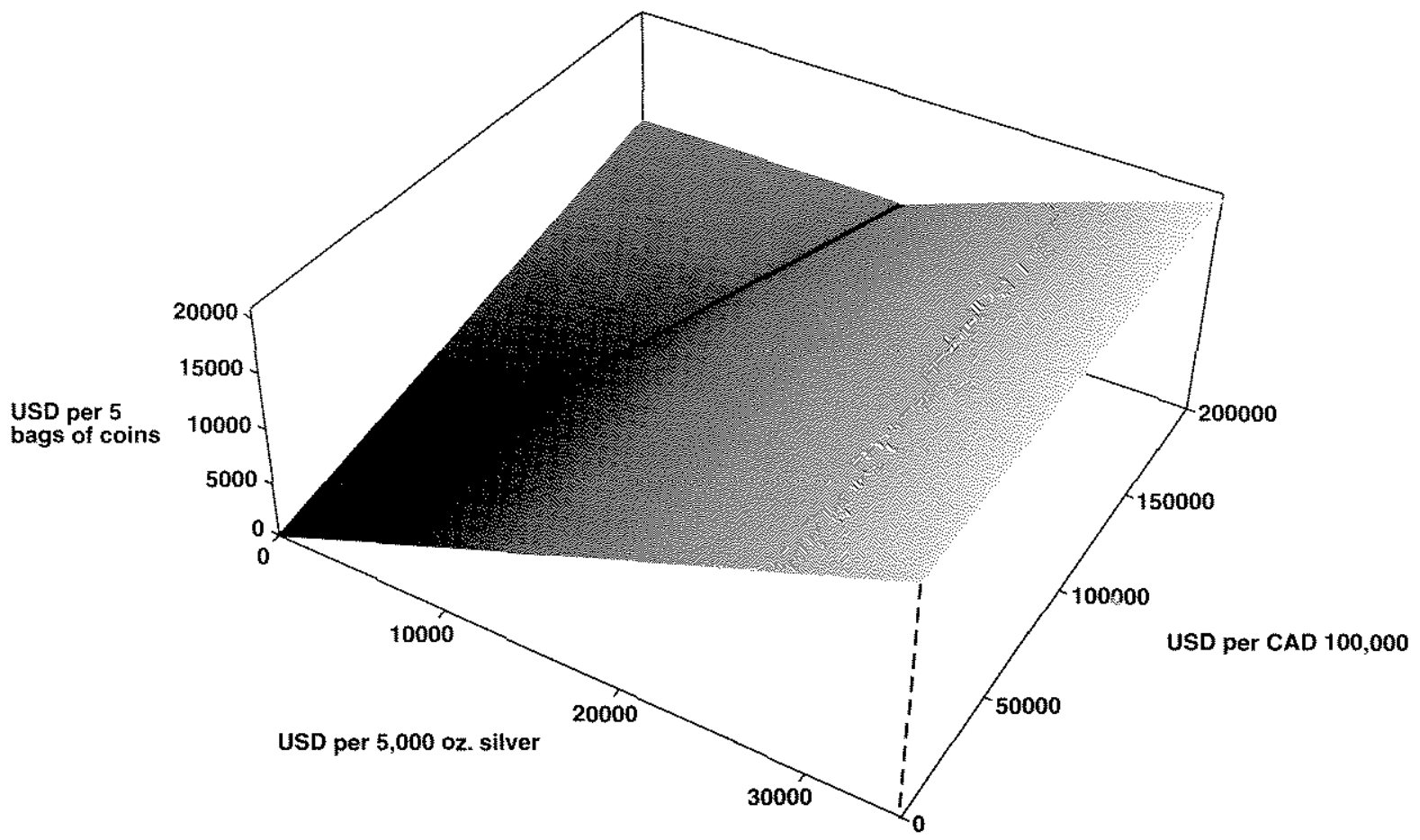

Board of Trade (CBOT). The surface is a graph of the function:

$\mathrm{V}_{\mathrm{c}}=\max \left\{0.05 \mathrm{~V}_{\mathrm{dt},}, 0.579 \mathrm{~V}_{\mathrm{st}}\right\}$,

where $V_{c 1}$ is the USD value of the five bags of coins at time $t, V_{d t}$ is the USD value of CAD 100,000 , and $V_{\mathrm{s}}$ is the USD value of 5,000 troy oz. of silver ${ }^{14}$

While this equation describes the relationships among spot prices for the three commodities, it does not address the price of the coinage futures contract directly. Two facts are relevant to our investigation at this point: First, futures contracts for both Canadian dollars and silver were actively traded at the time; second, the price of any futures contract must converge to the corresponding commodity spot price on the maturity date of the futures contract. The latter condition holds because, at maturity, arbitrage ensures that a contract for future delivery effectively becomes a contract for spot delivery. ${ }^{15}$
t4The coefficients, 0.05 and 0.579 , are simply the proportions of CAD 100,000 and 5,000 troy $0 z$. of silver, respectively, present in five bags of coins. The contract requires that the coins are worth CAD 5,000 ai face value, or 5 percent of CAD 100,000. The contract also specifies that "The coins must bear a minting date of 1966 or earlier except that an individual bag may contain up to $2 \% 1967$ or 1968 coins containing at least $\mathbf{5 0} \%$ silver ... The gross weight of each bag, including bag, seal, and tag shall not be less than 50.75 pounds [avoirdupois] for each [CAD] $\$ 1,000$ face amount;" emphasis in the original, IMM (1973b), p. 2. (Coins minted prior to 1967 were 80 percent silver by weight.) Deducting 0.75 pounds for the weight of the bag, and assuming that banks applied Gresham's law, that is, they chose their coins to minimize the silver content of each bag within the constraints of the contract, we find that each bag (CAD 1,000 face value) contained $39.7 \mathrm{lbs}$., or 578.9 troy oz. of silver. Thus, five bags contained 5789 percent of 5,000 troy $\mathrm{Oz}$. of silver.

15 For example, if the price of a maturing futures contract significantly exceeded the spot commodity price, then an arbitrageut could make unlimited, riskless profits by selling futures, buying spot and delivering the commodity. There is some margin for price discrepancies: this arbitrage is only profitable if the price difference exceeds the costs of fransaction and delivery. Still, only one arbitrageur is needed to enforce the arbitrage; the delivery and transaction costs for the least-cost arbitrageur should be the only relevant ones in this context. 


\section{Figure 2 \\ Daily Spot Prices of Silver and Canadian Dollars}

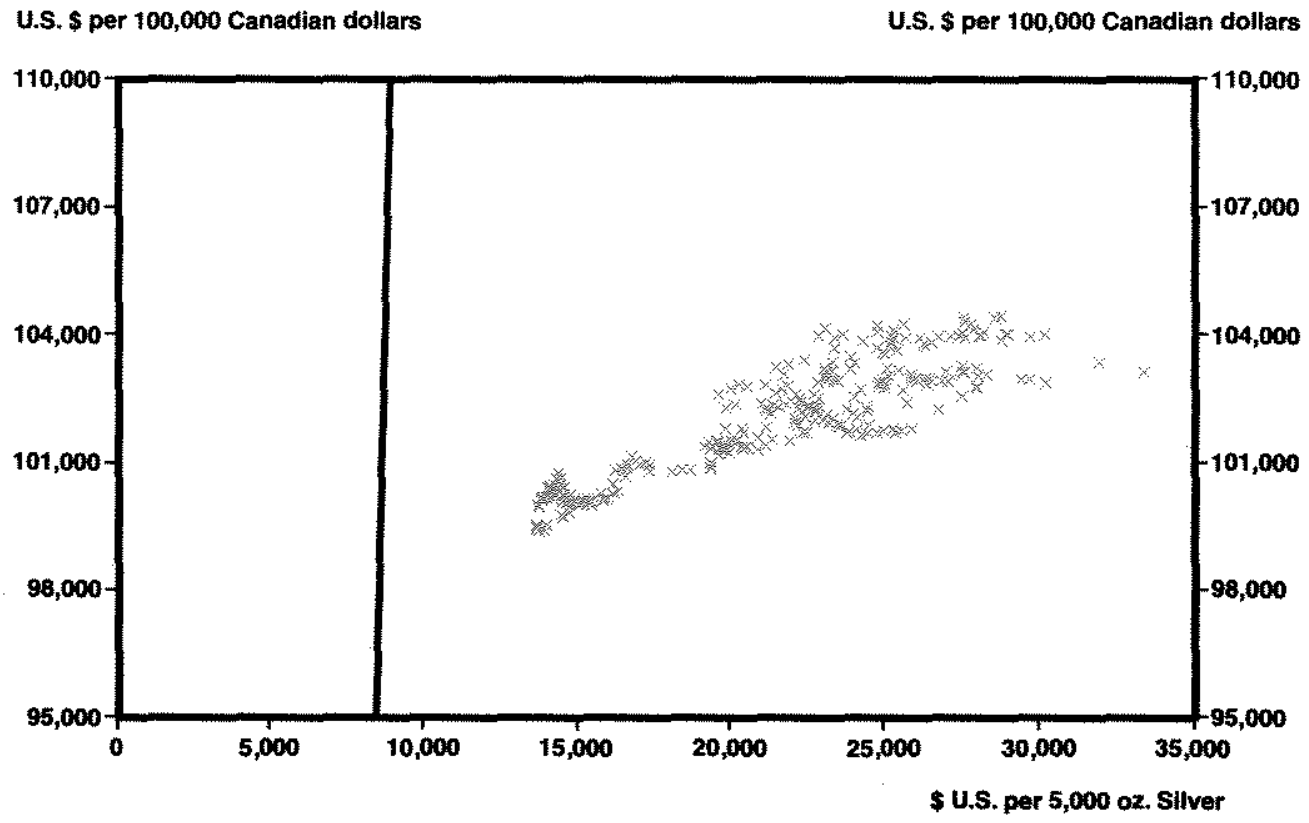

Given these relationships, we can restate our equation (approximately) in terms of the maturing futures contracts:

$V_{\mathrm{cT}} \approx \max \left\{0.05 V_{\mathrm{dT}}, 0.579 V_{\mathrm{sT}}\right\}$,

where $V_{\text {ст }}$ is the USD value of the coinage futures at the maturity date, $T, V_{d T}$ is the USD value of CAD futures, and $V_{S T}$ is the USD value of the silver futures. Assuming that delivery and transaction costs are negligible makes this equation exact: $V_{\mathrm{cT}}=\max \left\{0.05 V_{\mathrm{dT}}, 0.579 V_{\mathrm{sT}}\right\}$. This equation holds only at the maturity date of the futures contracts, however. At maturity, there is no uncertainty about which is larger, $0.05 V_{\mathrm{dT}}$ or $0.579 V_{\mathrm{sT}}$. Before maturity, $V_{\mathrm{d} \mathrm{T}}$ and $V_{\mathrm{sT}}$ are uncertain. ${ }^{16}$

As it turns out, this latter complication is largely academic. In hindsight, over the life of the coinage futures contracts, the coins were never more valuable as currency than they were as silver. Figure 2 graphs daily observations (scaled as in figure 1) of spot silver prices and the USD/CAD spot exchange rate for October 1973 through June 1974. The line in the graph corresponds to the crease in the surface of figure $1 .^{17}$ The fact that all points fall to the right of the line means that $\max \left\{0.05 \mathrm{~V}_{\mathrm{dt}}, 0.579 \mathrm{~V}_{\mathrm{st}}\right\}$ was always $0.579 \mathrm{~V}_{\mathrm{st}}$ (that is, that $0.579 \mathrm{~V}_{\mathrm{st}}>0.05 \mathrm{~V}_{\mathrm{dt}}$ ).

More significantly, it appears that, even before the fact, investors considered an outcome to the left of the line to be highly unlikely. If the probability of such an outcome is negligible (that is, if the probability is small that $0.05 V_{\mathrm{dt}}>0.579 \mathrm{~V}_{\mathrm{st}}$ ), then it is safe to use the approximation: $\max \left\{0.05 \mathrm{~V}_{\mathrm{dt}}, 0.579 \mathrm{~V}_{\mathrm{st}}\right\} \approx 0.579 \mathrm{~V}_{\mathrm{st}}$. Moreover, if this approximation always holds in the spot markets, it should also hold for futures

\footnotetext{
16We can still establish certain relationships between the prices, however. For times $\llbracket<T$, the possibility that the coins might be more valuable as currency than as silver provides a price floor for the coinage futures in terms of the silver futures: $v_{\mathrm{ct}} \geq 0.579 v_{\mathrm{st}}$. Similarly, we have a price floor for the coinage futures in terms of Canadian dollar futures: $v_{c t} \geq 0.05 v_{d t}$. Finally, because holding both silver and Canadian dollars at maturity must ałways be prefera-
}

ble to holding only the more valuable of the two, we can readily establish a price ceiling: $v_{\mathrm{ct}} \leq 0.579 \mathrm{~V}_{\mathrm{st}}+0.05 \mathrm{~V}_{\mathrm{dt}}$.

17 The crease in figure 1 is the set of points satisfying both $V_{c t}=0.05 V_{d t}$ and $V_{c t}=0.579 V_{s t}$. Thus, it is the line defined by $0.05 \mathrm{~V}_{\mathrm{dt}}=\mathrm{V}_{\mathrm{ct}}=0.579 \mathrm{~V}_{\mathrm{st}}$, of $\mathrm{V}_{\mathrm{dt}}=(0.579 / 0.05) \mathrm{V}_{\mathrm{st}}$. This is the line graphed in figure 2 . 
Figure 3

Daily Futures Prices for Silver and Canadian Coins

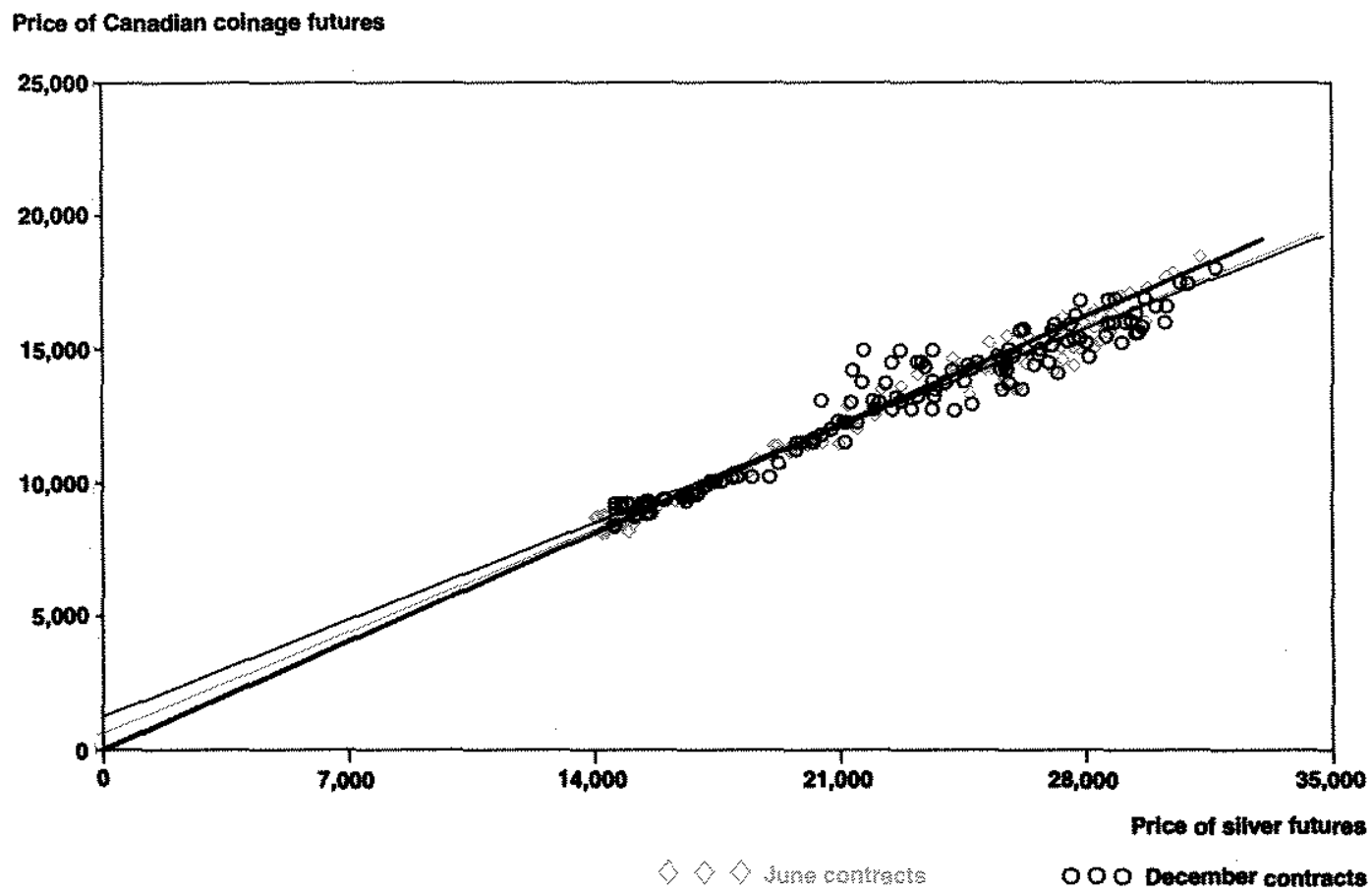

contracts; this implies we can use the approximation $V_{\mathrm{ct}} \approx 0.579 V_{\mathrm{st}}$.

The upshot of this is that, as long as investors could safely ignore the possibility that the coins would be more valuable as currency, a silver futures contract was a good cross-hedge for the coins. In other words, the value of the coins would be determined solely by their silver content, rather than their potential use as Canadian currency - the value of the coins should move in tandern with silver prices. Conversely, if all the points were to lie on the left side of the line in figure 2 instead of the right, the opposite condition would hold: the CAD futures contract would be the appropriate cross-hedge to consider, and we could disregard the silver contract.

The usefulness of silver futures as a crosshedge is confirmed in figures 3 and 4 . Figure 3 plots daily price observations for silver futures and Canadian coinage futures maturing in June 1974 and December 1974. The bold line through the origin is the theoretical relationship under redundancy: $V_{\mathrm{rt}}=0.579 \mathrm{~V}_{\mathrm{st}}$.

The other two lines are regression lines (lines of best fit) for the two different maturities. ${ }^{18}$ Given our regression results, we can be more specific about the effectiveness of a cross-hedge. The coefficient of determination, or $\mathbf{R}^{2}$ statistic, from such a regression is a standard measure of

${ }^{18}$ These regressions show that the behavior of silver futures prices and that of coinage futures prices are very similar, implying that these two potential hedging instruments are essentially indistinguishable from a pricing standpoint. An alternative would have been to demonstrate their hedging effectiveness directly, by regressing spot coin prices first on coinage futures prices and then on silver futures prices. A spot price series for Canadian silver coins was not available, however. 


\section{Figure 4 \\ Daily Prices for December 1974 Silver and Canadian Coin Futures}

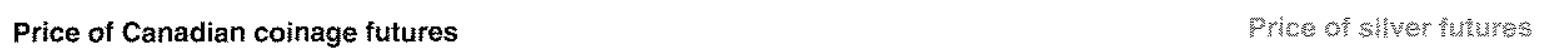

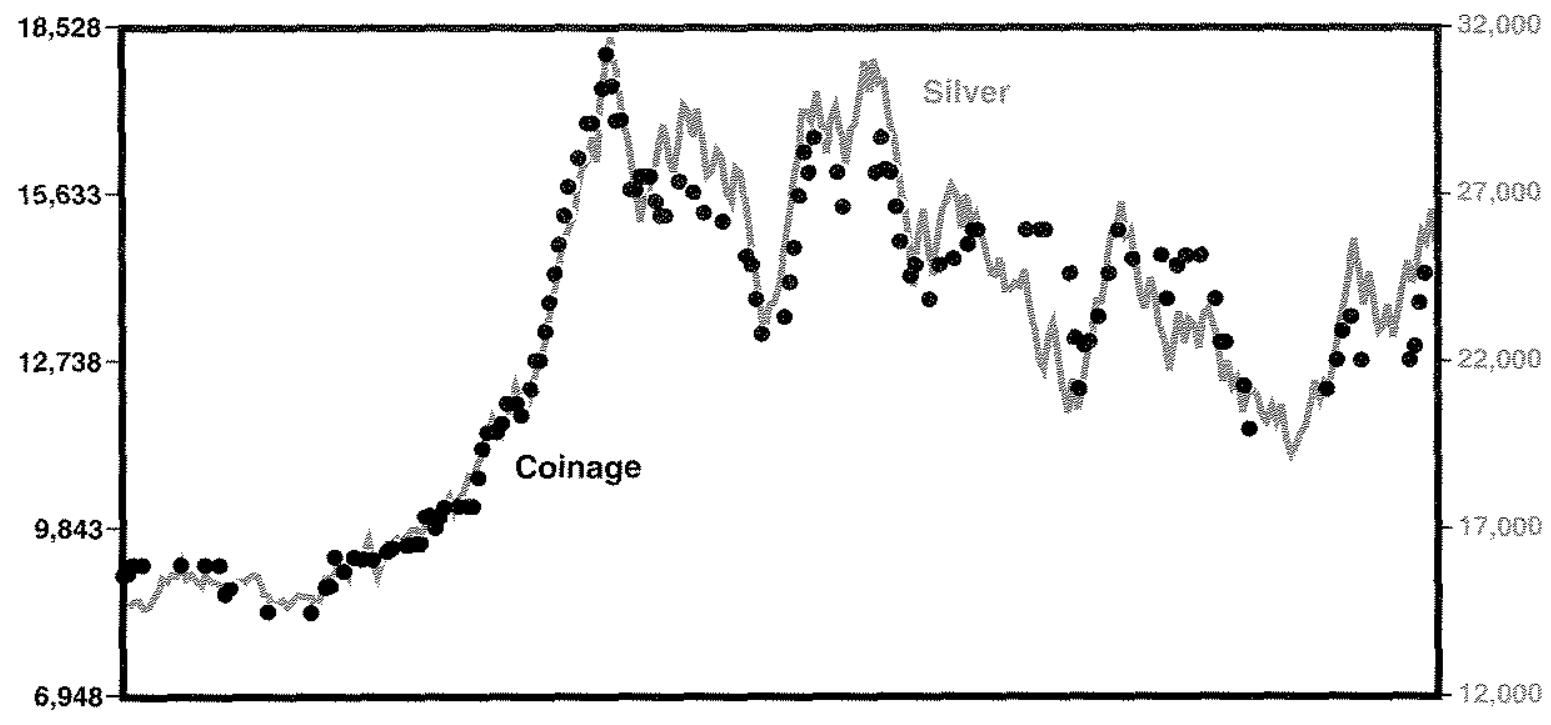

October 1,1973 to October 25,1974

the effectiveness of a hedge. The $\mathrm{h}^{2}$ statistic can vary from 0.00 for a useless hedge to 1.00 for a perfect hedge. For the regressions on the June and December contracts, the $\mathrm{R}^{2}$ statistics were 0.973 and 0.933 , respectively. ${ }^{19}$ The implication is that silver futures moved closely together with coinage futures, and thus could serve as an excellent cross-hedge: Imvestors could have achieved almost identical results with the silver contract as with the coinage futures. This is confirmed in figure 4 , which shows the same relationship plotted as time series of the two prices. Silver and coinage futures prices moved in near lockstep. ${ }^{20}$

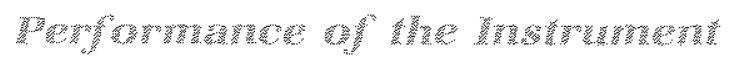

Having established the existence of a serviceable eross-hedge for the Canadian coinage futures contract, we now examine the contract from the perspective of the innovator. From this perspective, the contract is successful to the extent that it profits the innovator. The innovator in this case was an organized futures exchange, the IMM, owned by the members of the exchange. The membership of a futures exchange consists of its traders, who benefit from an increase in trading volume through higher
19 We can compare these numbers to the hedging effectiveness of CAD futures. As expected, a regression of the price of coinage futures on the price of CAD futures yields lower $\mathrm{R}^{2}$ statistics, implying that silver futures were a better cross-hedge. The $R^{2}$ was 0.568 for the June contracts and 0.715 for December.

The use of the $\mathrm{R}^{2}$ originated with Ederington (1979), pp. 163-64. The standard measure is based on regressions of returns on returns, rather than prices on prices, as are shown in the figure. Because the coinage futures had no recorded price on most days (due to no trading), however, it was not possible to construct a daily return series. An imperfect alternative is to calculate returns from one price observation to the next, producing a time series of returns with irregular holding periods. The $\mathrm{R}^{2}$ statistics for these regressions are 0.385 for the June contract and 0.419 for the December contract.

In comparison, Johnston and McConnell (1989) report on Government National Mortgage Association (GNMA) Collateralized Depository Receipt (CDR) futures contracts. Dur. ing the most successful years of the contract, 1980-82, the hedging effectiveness $\left(\mathrm{R}^{2}\right)$ of the futures contract for the underlying GNMA securities over five-day hoiding periods ranged from .85 to .94 . During the contract's leanest years, $1983-85$, the $R^{2}$ ranged from .54 to .62 percent, making it a less effective hedge than a Treasury bond futures contract.

20Because of low volume in the coinage futures market, there were many days with no bids or offers submitted and, therefore, no posted settlement prices. 
turnover or through greater liquidity. ${ }^{21}$ For our purposes, we can proxy for profits by measuring trading volume in the contract.

Illiquidity can be costly to traders in two ways. First, traders may be forced to search actively for counterparties with whom to trade; searching consumes time and resources. Second, traders who are delayed by the search process face price risk: the price of their commodity can change before they locate a counterparty. In general, a trader would require some remuneration before bearing such a risk willingly. One of the primary economic functions of an organized exchange is to bring traders together in the same place, to obviate such search costs. There is a recursive catch in the economic logic here, however: traders may not be attracted to a market if it is not liquid, but a market may not be liquid unless traders are attracted to it.

Trading volumes for the June and December coinage contracts, however, were never large. On most days, fewer than five contracts changed hands. There were many days with no trades. Of 183 trading days for the June contract, there were 66 days when only a bid quote or only an ask was available; neither was available on 78 days. For the December contract, 92 of 310 trading days had only one side of the market present, and on 181 days neither side was available. ${ }^{22}$ Trading volume peaked at 45 contracts on October 31, 1973; in comparison, for the CBOT's silver futures, several thousand contracts changed hands on a good day in $1973 .^{23}$ By October 1974, trading in the Canadian coinage futures had dwindled to almost nothing. The last recorded trade came on October 25 , 1974, when a single December 1974 contract changed hands.

In hindsight, we have a theoretical explanation for the contract's failure. Futures contracts for Canadian silver coins should have been at- tractive to owners of silver coins, who wanted to hedge the value of their coins against price fluctuations, and speculators, who were willing to bet they could predict those price changes more accurately than the rest of the market. A comparison of prices reveals that existing silver futures were a close substitute for the coinage futures as a hedging/speculating tool. Moreover, the long-established silver contract traded in a much more liquid market. 'Thus, hedgers and speculators had in the silver contract most of the benefits of the coinage contract as a hedg. ing instrument, without most of the drawbacks associated with illiquidity. In this context, then, the silver futures should be seen as uniformly preferable to the coinage futures.

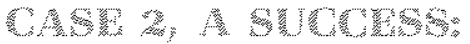

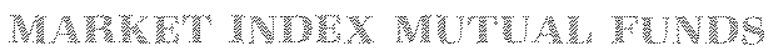

We turn now to a successful innovation: market index mutual funds. The size of the particular fund chosen as an example has grown steadily since its introduction in 1976. Although an index fund is little more than a repackaging of other securities, with little decision-making discretion left to the fund's management, such funds can succeed by reducing the costs of transacting for individual investors.

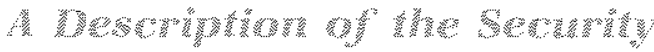

On August 31, 1976, the Vanguard Group introduced the "500 Portfolio," a stock market mutual fund whose specific objective is to track the Standard and Poor's 500 stock market index (S\&P 500). In the language of the fund's prospectus, "the 500 Portfolio seeks to replicate the aggregate price and yield performance of the Standard \& Poof's 500 Composite Stock Price Index. ... The 500 Portfolio invests in all 500 stocks in the S\&P 500 Index in approxi-
${ }^{21}$ See Black (1986), pp. 19-21. There is no universally accepted definition for the term "liquidity." It is usually associated with an absence of search costs. See Demsetz (1968), Tinic (1972) and Logue (1975) for further discussion.

22Figure 4 includes prices for the coinage contract for many days on which trading volume was zero. The exchange posted settlement pices on many days when either bids or offers appeared but no trading occurred.

${ }^{23} \mathrm{~A}$ related measure of the coinage contract's lack of popularity is open interest (the sum of all traders' net long positions in the contract, also called committed contracts). The same picture of a thin and illiquid market emerges. Open interest in the June 1974 contract peaked in May 1974 at 56 committed contracts. For the December 1974 contract, the peak of 37 committed contracts was reached in October 1973. Again, in comparison, open interest for the CBOT's silver contract reached tens of thousands of committed contracts during this time. 
mately the same proportions as they are represented in the Index."24

There are good reasons why we might expect a market index mutual fund to be unattractive to investors. First, it is inflexible. For example, an investor in an index fund who wanted to divest any stake in, say, petroleum stocks would have to sell her entire stake in the fund. In contrast, an investor holding the same stocks directly could sell petroleum stocks without affecting her other positions. Second, a mutual fund introduces a middle man: The fund must be compensated for its investment management services, which, for an index fund, are essentially papershuffling. The allocation of assets in an index is set by a predetermined rule, which an investor could follow on his own.

On the other hand, there are also reasons why investors might find an index fund attractive. First, despite the inflexibility of rule-based indexes, some investor's might be attracted to a specific index, so that the inflexibility of that index would not be a binding constraint for those investors. The standard capital asset pricing model, for example, concludes that all investors should hold a value-weighted portfolio of all available assets to achieve the best risk-return trade-off. ${ }^{25}$ Although the S\&.P 500 does not contain all assets, it is well diversified, it is valueweighted, and it is widely known. Perhaps for this reason, the S\&P 500 has become an indus. try benchmark. ${ }^{26}$

Assuming there is a special interest in the S\&P 500 as an investment portfoho, we still must explain the popularity of a mutual fund as a preferred means of holding that portfolio. Gorton and Pennacchi (1991) construct an elaborate rationale for security baskets as a way for uninformed traders to exploit the inflexibility of a market index to diversify themselves against losses to insider trading. A plausible, although more prosaic, reason is that mutual funds might be a way to spread the fixed costs of stock market trades over many investors, thus lowering the average cost faced by each investor. These costs can be significant. Since stock prices generally change many times in one day, the number of transactions required to maintain a theoretically exact index portfolio of 500 stocks is potentially enormous. As long as there is a non-zero fixed cost per trade, the sum of these fixed costs of maintaining the index will be proportionately large.

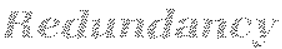

We saw in the first case that the prices of Canadian coinage futures contracts were tracked almost exactly by the prices of silver futures; the coinage futures were redundant. We now perform a similar analysis on the index fund and demonstrate that it too is redundant: the value of the fund is closely tracked by the value of the index. In this case, however, the managers of the fund have actively pursued exactly this correlation as their stated purpose. Redundancy here helps explain the innovation's success.

Figures 5 and 6 are analogous to figures 3 and 4 , respectively. Figure 5 plots daily price observations for the Vanguard 500 Portfolio and the S\&P 500. We see that the fund price and the index value move tightly together. Upon closer examination, the prices seem to be confined to a collection of line segments radiating from the origin and rotating downward as one moves further out. The line segments are periodically bumped downward, as maintenance fees, operating charges and dividend and capital gains distributions tend to be concentrated in

${ }^{25}$ See, for example, Fama (1976), chapters 7 and 8.

26 There are other commonly used benchmark indexes, for example, the $S \& P 100$, the Wilshire 5000 Index, or the Dow Jones Industrial Average.
${ }^{24}$ Vanguard Index Trust (1992), p. 9. For those unfamiliar with hold investments, it is important to note that a buy-andcomposition of an index portolio (i. e., the number of shares of each stock) depends on the prices of all the stocks in the index. Therefore, in contrast to a buy-andhold investment, the composition of a theoretically exact index portfolio changes every time the price of any one of its component securities changes. A dynamic investment strategy is required for an index portfolio.

Vanguard is only one of many companies to offer an S\&P 500 index mutual fund for investors. Its use as an example should not be interpreted as a recommendation for or against this or any other mutual fund. There are also other ways of investing in the S\&P 500 index, including index futures and index options. 
Figure 5

Daily Values for the S\&P 500 Index and the 500 Portfolio

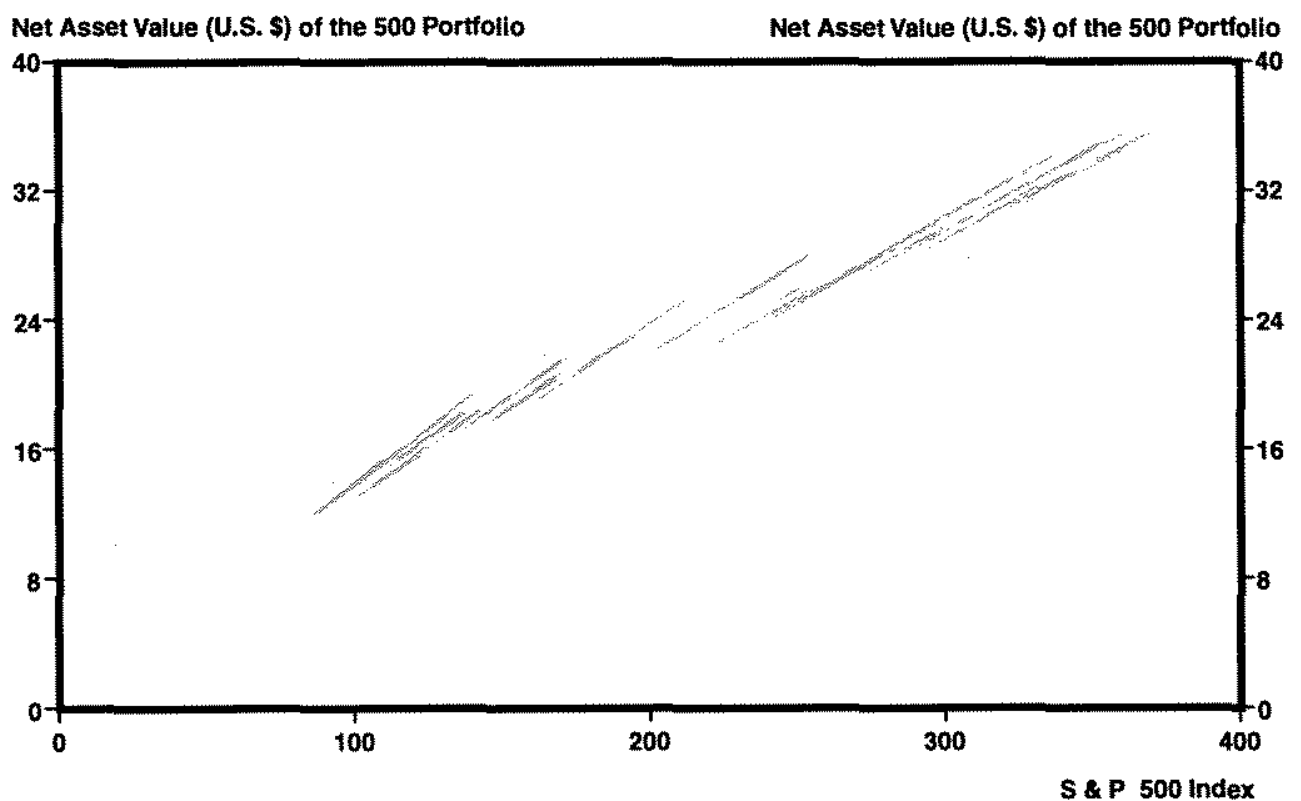

Figure 6

Daily Values for the S\&P 500 Index and the $\mathbf{5 0 0}$ Portfolio

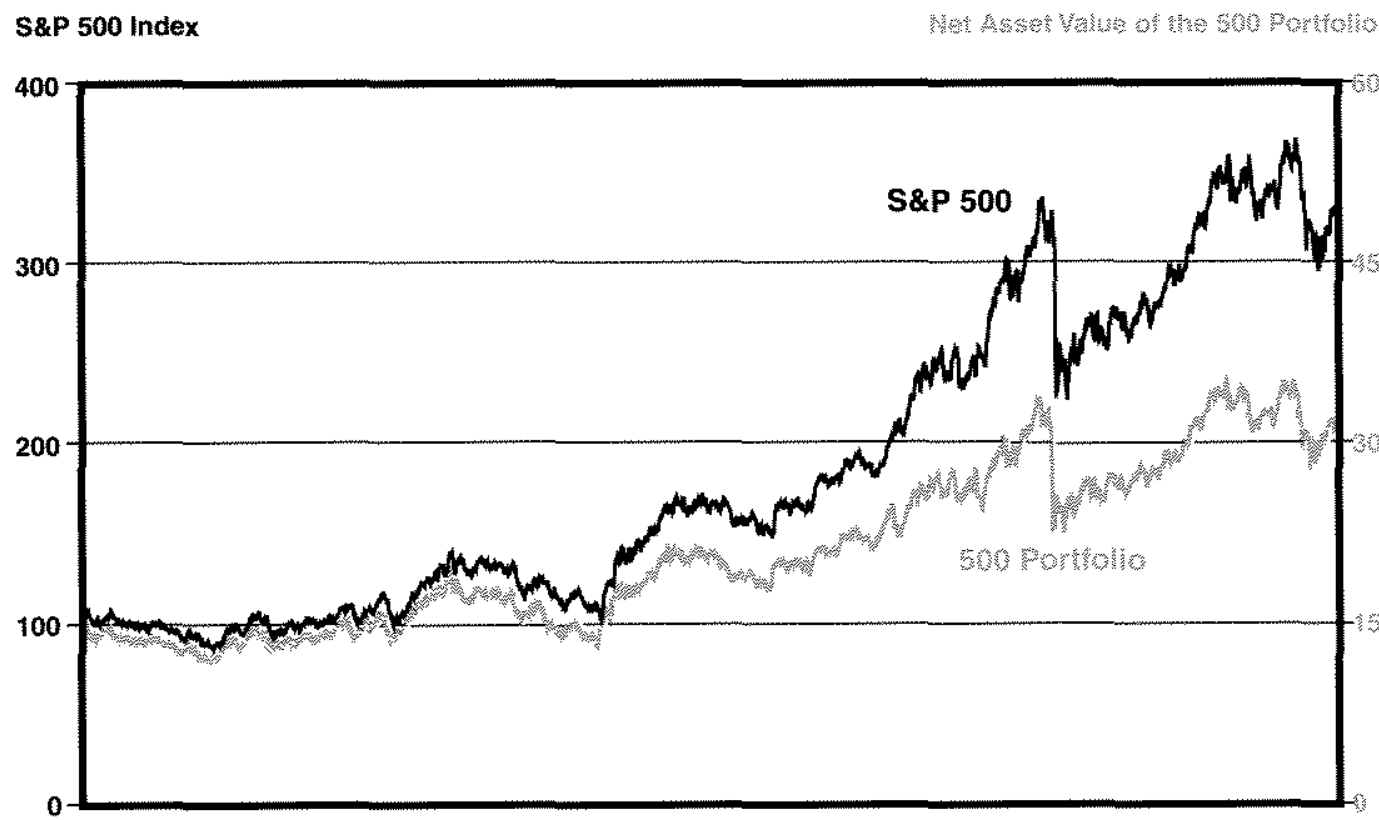

September 1, 1976 to December 31, 1990 
cumulative year-end adjustments. ${ }^{27}$ The line segments also tend to move successively outward over time, because of the general upward trend in stock prices over time. Even with these discontinuities, however, a regression of five-day. holding.period mutual fund returns on S\&P 500 returns yields an $\mathrm{R}^{2}$ statistic of 0.978 ; according to the standard measure, the mutual fund is a nearly perfect hedge for the S\&P $500{ }^{28}$

Figure 6 shows the same relationship, but with the 500 Portfolio values and index values plotted as time series. Over relatively long periods of time, the value of the index grows at a slightly higher rate than the value of the mutual fund. This long-run discrepancy reflects the fact that the index is a theoretical portfolio - one that assumes transaction costs are zero. ${ }^{29}$ The mutual fund, on the other hand, charges each shareholder a fixed quarterly account maintenance fee, plus operating expense charges equal to .2 percent of the value of the fund over the course of each year. Over time, these fees accumulate and compound to produce a discrepancy.

\section{Pron}

We turn now to the question of the innovation's success. For this, we need a measure. The innovator in this case was the fund's manager, the Vanguard Group. We therefore define a success as an innovation that profits them. For an index fund, unlike many other forms of intermediation, the manager profits only through, its fees. The fund receives periodic fees from its shareholders, while incurring the costs of fund management: accounting, buying and selling stocks, receiving and disbursing payments, etc. Data on management costs were unavailable, however, so that profits could not be measured directly.

Instead, we assume that the fund's profits are increasing with revenues over the entire range considered here. Under this assumption, profits increase with the size of the fund. We therefore use the size of the fund as our measure of success. ${ }^{30}$ Figure 7 shows the size of the fund both nominally and in constant (CPI-adjusted) 1983 dollars. Almost since its inception in 1976 , the value of the fund has grown exponentially. In nominal terms, the fund currenty contains $\$ 4.346$ billion, or $\$ 3.176$ billion in constant 1983 dollars.

One plausible explanation of the success of an index mutual fund is transaction costs. Like many expenses, the cost to an individual investor of a stock purchase can be divided into a variable and a fixed portion: price per share times number of shares plus a brokerage commission. If large numbers of investors wish to hold the index, and if the size of a brokerage commission is fixed, or at least insensitive to the quantity transacted, then the investors can pool their transactions to reduce the total amount of commissions paid. A mutual fund is one way to achieve this pooling of investments.

Although the mutual fund falls short of the index in the long run, the relevant comparison is not with a theoretical entity, but with those alternatives that are available on a practical basis. While everyone acknowledges the presence of transaction costs, some might argue that these costs are too small in modern financial markets to make a difference. Gorton and Pennacchi, for example, suggest that "investors can costlessly replicate [these composite securities],"3.1.
27Because of differences in the way the index and the mutual fund account for dividends and capital gains, tracking the net asset value of the mutual fund tends to understate its performance relative to the index. In particular, the index generally assumes that dividends, stock splits, etc., are reinvested, adjusting the index accordingly, while the mutual fund gives investors the option of collecting their dividends and capital gains. Unfortunately, sufficient information was not available to make accurate compensating adjustments to the net asset values of the fund.

28Performing the same analysis with daily returns, the $R^{2}$ statistic is 0.859 . The drop in significance is attributable to the fact that returns for one-day holding periods are smaller than for five-day holding periods, relative to noise factors such as rounding errors.

29As noted in footnote 27 , the mutual fund time series presented here tends to understate its performance relative to the index. If we were able to compensate for disburse- ments, the compensated mutual fund price path would lie above the net asset values shown here, but still below the curve for the S\&P 500. The average annual return calculated for the mutual fund on a compensated basis was 13.9 percent over the period $8 / 31 / 76$ to $12 / 31 / 91$, compared with 14.4 percent for the index. See Vanguard Index Trust (1992), p. 16 .

${ }^{30} \mathrm{~A}$ full discussion of the relationship between the size of the fund and Vanguard's profits, and therefore of Vanguard's incentives to innovate, would require consideration of issues of returns to scale and market structure that are beyond the scope of this paper.

${ }^{31}$ Gorton and Pennacchi (1991), p. i. They go on to state (p. 2) that "the popularity of such composite securities seems puzzling since consumers, on their own, can apparently accomplish the same resulting cash flow by holding a diversified portfolio of the same securities in the same proportions." 


\section{Figure 7 \\ Size of the $\mathbf{5 0 0}$ Portfolio}

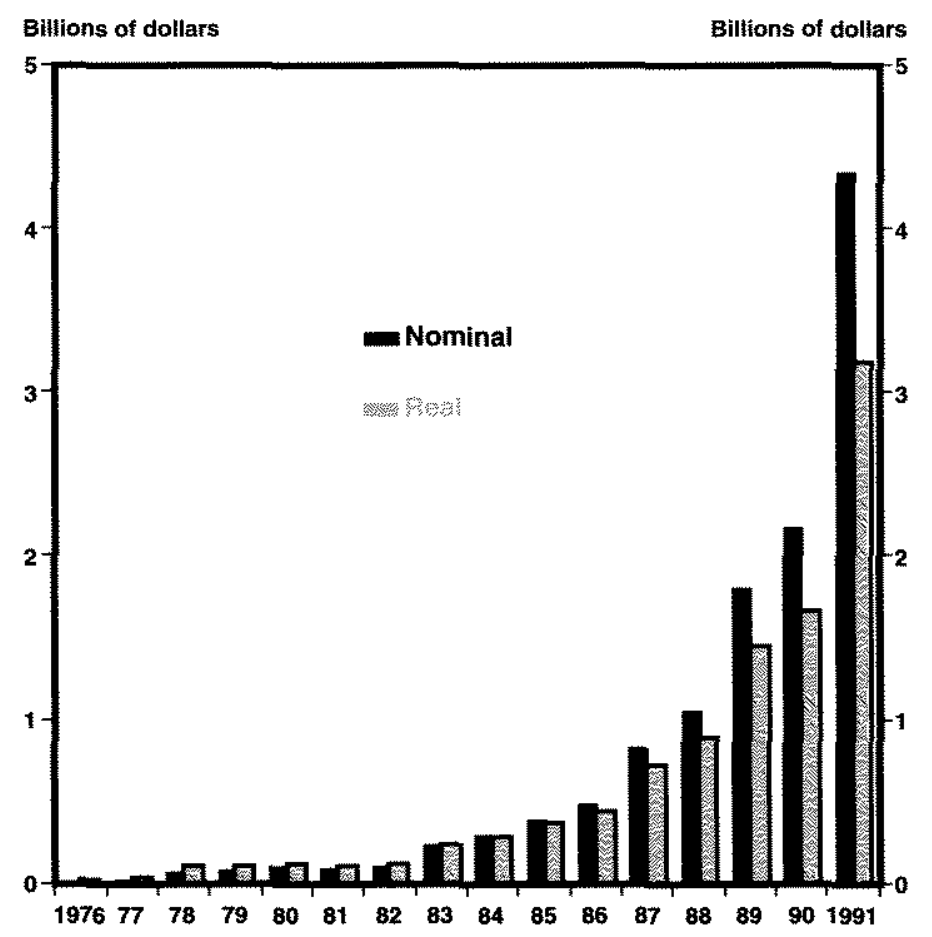

To demonstrate the potential role of lower transaction costs in the success of the mutual fund, consider the performance of an index portfolio managed directly by an individual investor trading through a brokerage house and facing realistic brokerage commissions. To make this example plausible, we consider pre-tax returns on an S\&P 500 portfolio for an investor making a modest number of trades each day and able to transact at standard brokerage com. mission rates. In particular, we consider an initial net investment of $\$ 1$ million in the S\&P 500 index made on September 1, 1976. Assume that our investor is able to track the index (approximately) by making 10 trades per day at an average cost of $\$ 30$ per trade. ${ }^{32}$ Brokerage commissions on this portfolio thus absorb $\$ 300$ per day.

Figure 8 compares the results for this portfolio with those for the mutual fund over the life of the fund. The results are straightforward: over the course of almost 15 years, the value of the index held directly has fallen to about $\$ 860,000$ in nominal terms, while the mutual fund has posted a $\mathbf{1 1 9 . 2}$ percent gain. If we were to adjust for inflation and dividends, the poor performance of the direct portfolio would be even more striking. The result is that investors who would otherwise have to trade at standard brokerage rates can hold the index more cheaply as a mutual fund. Indeed, given such transaction costs, it appears likely that an index portfolio managed by an individual investor would have negative ex ante returns. If this were the cheapest means of doing so, no one would want to hold an indexed portfolio.

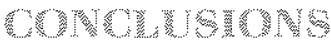

The foregoing has presented two case studies of financial innovations. One innovation, Canadi-

\footnotetext{
32 Brokerage commission schedules are complex and vary considerably from one broker to another. Some of the factors that can affect the commission on a trade are volume discounts, odd-lot trading premia, and negotiated commissions for very active customers. The average $\$ 30$ fee used
}

here is based on a commission rate of 1 percent of the to. tal price of each transaction, an average share price of $\$ 30$ per share, and trading in single round lots of 100 shares. 


\section{Figure 8}

\section{An Index Portfolio Subject to Transaction Costs}

Direct Portfolio Value (Millions of dollars)

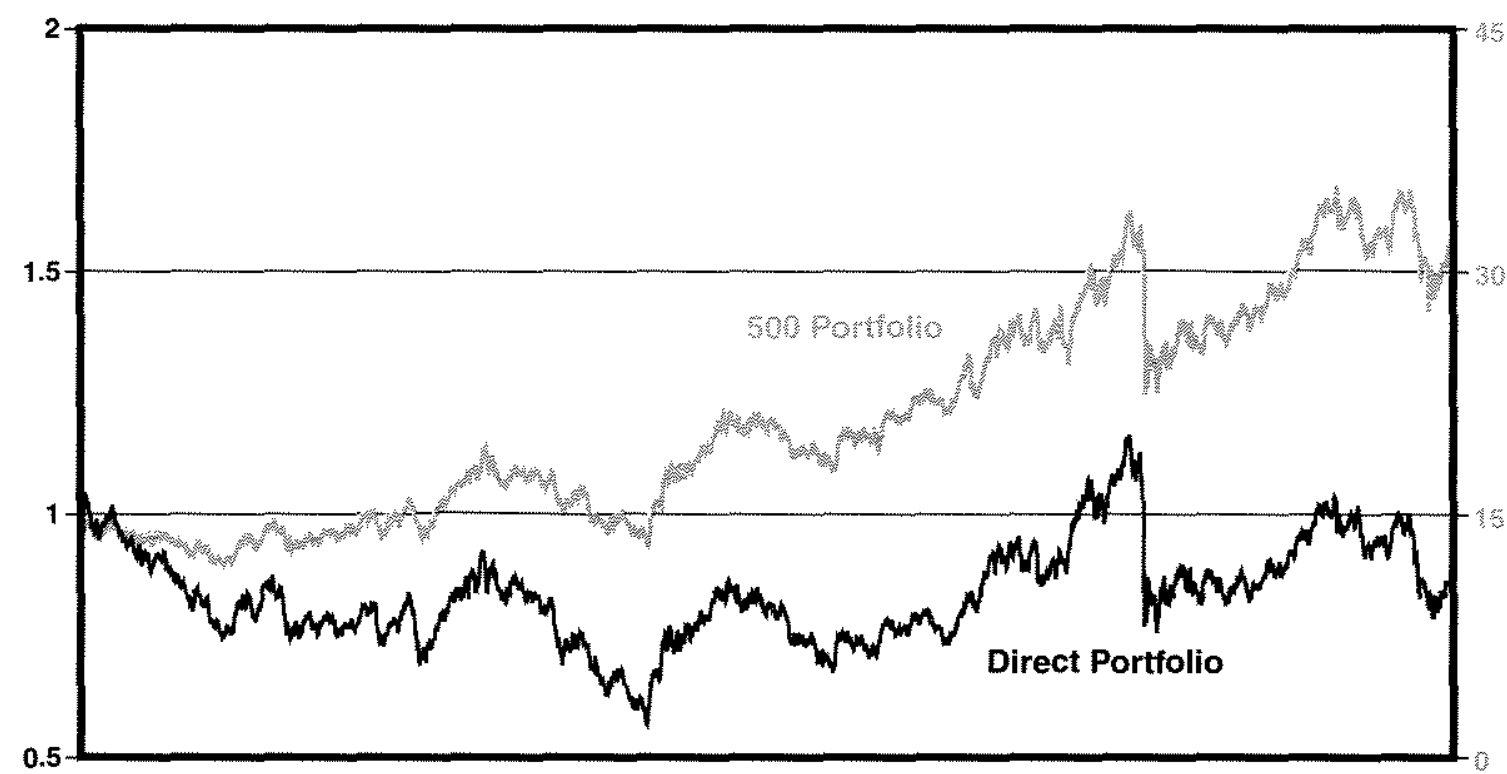

September 1, 1976 to December 31, 1990 an silver coin futures, failed. The other, a market index mutual fund, has succeeded. Together, the two case studies represent an experiment of sorts. We have examined two innovations with a common feature: Both were redundant in the technical sense that their price movements were closely tracked by the price movements of other securities. One might say that the first failed be cause it was redundant, while the latter has succeeded for the same reason.

This conclusion is more compelling if we state it as the following more general proposition: Given two securities with redundant prices that is, two that are perfect hedges for one another) investors will be drawn to the one with the lower transaction and liquidity costs. If there is no investor clientele for which a redundant security is the cheaper to employ, then that security will fail.

When stated in these terms, the conclusion seems obvious. Nonetheless, this proposition is not universally observed. It requires an explicit acknowledgement of the fact that transaction and liquidity costs can be significant factors in the financial marketplace. This runs contrary to the common assumption in financial economics that capital markets are "perfect," which implies, among other things, that transaction costs are zero. While such an assumption may be appropriate in certain applications, a full understanding of the behavior of financial markets and innovations requires an appreciation of these various hindrances to exchange. Thus, to the extent that financial frictions such as transaction and liquidity costs represent real resource drains on an economy, successful financial innovations should normally be regarded as welfareenhancing. By replacing cumbersome or inefficient modes of exchange, successful innovations can make everyone involved better off.

\section{MPPERENOS}

Alchian, Armen A. Economic Forces at Work (Liberty Press, $1977)$.

Allen, Franklin, and Douglas Gale. "Optimal Security Design," Review of Financial Studies 1 (Fall 1989), pp. 229-63.

American Bankers Association. "Facts About the New U. S. Coins," (ABA, 1965). 
Black, Deborah G. "Success and Failure of Futures Contracts: Theory and Empirical Evidence," Monograph Series in Finance and Economics, Salomon Brothers Center for the Study of Financial Institutions (New York, 1986).

Board of Governors of the Federal Reserve. "Interpretation of Regulation D: Currency or Coin Held Principally for its Numismatic or Bullion Value," Federal Reserve Bulletin (December 1970), p. 942 .

Chen, Andrew $H_{\text {., }}$ and John $W$. Kensinger. "Creating Contingent Liabilities: Master Craftsmanship in Financial Engineering," in Game Plans for the "90s: Proceedings of the 26th Annual Conference on Bank Structure and Competition, May 9-11, 1990 (Federal Reserve Bank of Chicago, 1990), pp. 199-223.

Demsetz, Harold. "The Cost of Transacting," Quarterly Journal of Economics (February 1968), pp. 33-53.

Ederington, Louis $\mathrm{H}$. "The Hedging Performance of the New Futures Markets," Journal of Finance (March 1979), pp. $157-70$.

Fama, Eugene F. Foundations of Finance (Basic Books, 1976).

Flood, Mark D. "An Introduction to Complete Markets," this Revjew (March/April 1991), pp. 32-57.

Friedman, Milton. "Financial Futures Markets and Tabular Standards," Journal of Political Economy (February 1984). pp. $165-67$.

Goldsmith, Raymond W. Premodern Financial Systems, A Historical Comparative Study (Cambridge University Press, $1987)$

Goodhart, Charles. "Financial Innovation and Monetary Control," Oxford Review of Economic Policy (Winter 1986), pp. 79-102.

Gorton, Gary, and George Pennacchi. "Security Baskets and Index-Linked Securities," NBER working paper No. 3711 (May 1991).

Intemational Monetary Market of the Chicago Mercantile Exchange, Inc. A Guide to Siver Coin Futures Trading (IMM, 1973a).

"Chapter 15: Canadian Silver Coins," Rules of the International Monetary Market of the Chicago Mercantile Exchange (CME, 1973b).

International Monetary Market Vear Book 1973-1974

(IMM, 1974).
Johnston, Elizabeth Tashjian, and John J. McConnell "Requiem for a Market: An Analysis of the Rise and Fall of a Financial Futures Contract," Review of Financial Studies 2 (1989), pp. 1-23.

Kane ${ }_{+}$Edward J. "Good Intentions and Unintended Evil: The Case against Selective Credit Allocation," Journal of Money, Credit and Banking (February 1977), pp. 55-69.

"Microeconomic and Macroeconomic Origins of Financial Innovation," in Financial Innovations: Their Impact on Monetary Policy and Financial Markets (Kluwer-Nijhoff, 1984), pp. 3-20.

Logue, Dennis E. "Market-Making and the Assessment of Market Efficiency," Journal of Finance (March 1975), pp. 115-23.

Marton, Andrew. "How much is too much?" Institutional investor (August 1984), pp. 238-50.

Milter, Merton H. "Financial Innovation: The Last Twenty Years and the Next," Journal of Financial and Quantitative Analysis (December 1986), pp. 459-71.

. Financial Innovations and Market Volatility (Basil Blackwell, 1991).

Podolski, T. M. Financial innovation and the Money Supply (Oxford: Basil Blackwell, 1986).

Rasche, Robert H. "Monetary Policy and Financial Deregulation in the United States," Kredit und Kapital (Heft 3, 1988), pp. $451-68$.

Schumpeter, Joseph A. Business Cycles: A Theoretical, Historical, and Statistical Analysis of the Capitalist Process, Volume I (McGraw-Hill, 1939).

Silber, William L. "Innovation, Competition, and New Contract Design in Futures Markets," Joumal of Futures Markets (Summer 1981), pp. 123-55.

"The Process of Financial Innovation," American Economic Review (May 1983), pp. 89-95.

"Towards a Theory of Financial Innovation," in Wiliam L. Silber, ed., Financial innovation (Lexington Books, 1975), pp. 53-85.

Simpson, Thomas D. "Changes in the Financial System: Implications for Monetary Policy," Brookings Papers on Economic Activity (1:1984), pp. 249-65.

Tinic, Seha M. "The Economics of Liquidity Services," Quarterly Journal of Economics (February 1972), pp. 79-93.

Vanguard Index Trust. Prospectus: March 15, 1992; Revised April 10, 1992 (Valley Forge: The Vanguard Group, 1992). 